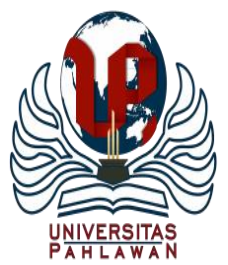

Edukatif : Jurnal Ilmu Pendidikan Volume 3 Nomor 4 Tahun 2021 Halm 2321 - 2328

EDUKATIF: JURNAL ILMU PENDIDIKAN

Research \& Learning in Education

https:/ledukatif.org/index.php/edukatif/index

\title{
Social, Nature, Religion Morality and Protecting of Pencak Silat Cimande
}

\author{
Bahagia Bahagia $^{1 凶}$, Rimun Wibowo², Dede Dede ${ }^{3}$, Fitri Amelia ${ }^{4}$, Kartika Amelia ${ }^{5}$, Ilham Nur \\ Hidayat $^{5}$, Mulyana Kosasih ${ }^{7}$ \\ Universitas Ibn Khaldun Bogor, Indonesia ${ }^{1,4,5,6}$ \\ LPM Equator Bogor, Indonesia ${ }^{2}$ \\ Perguruan Padjadjaran Cimande, Indonesia ${ }^{3,4}$ \\ E-mail : bahagiagia59@yahoo.co.id ${ }^{1}, \underline{\text { rimunwibowo@gmail.com }}^{2}, \underline{\text { doankdede027@gmail.com }}^{3}$
}

\begin{abstract}
Abstrak
Pencak silat termasuk budaya bangsa Indonesia yang berperan untuk membentuk aklah kepada lingkungan. Penelitian bertujuan untuk menemukan nilai-nilai akhlak dan konservasi Pencak silat Cimande. Metode penelitian yang digunakan yaitu metode kualitatif. Pengumpulan data dengan observasi, wawancara mendalam, dan dokumentasi. Pemilihan informan dengan teknik purposive sampling. Anaslisis data dengan pendekatan triangulasi data. Hasil temuan menunjukkan bahwa Pencak silat Cimande memiliki nilai-nilai akhlak kepada Tuhan, manusia dan lingkungan hidup. Lawan kalau sudah kalah harus dihormati dengan cara tidak memukul lawan dan menghina lawan serta tidak boleh mengejak lawan. Demikian hal kepada alam, anggota Cimande tidak boleh buang sampah ke sungai dan memperlakukan makhlak hidup seperti hewan dengan baik. Temuan lain yaitu Pencak silat Cimande harus dilestarikan agar tetap bisa berkelanjutan kepada generasi muda melalui literasi kepada pemuda tentang silat, memodifikasi metode silat sehingga sesuai dengan keadaan masa kini, pengkategorian terhadap para pemain silat mulai dari junior dan senior dengan cara diberikan perbedaan warna sabuk. Cara lain yaitu melakukan training dan menjadikan anak-anak sekolah sebagai anggota silat. Temuan lain terdapat nilai-nilai kesehatan dari permainan silat Cimande dan mengandung nilai-nilai agama serta terdapat nilai nilai sosial dari kegiatan Pencak Silat Cimande.
\end{abstract}

Kata Kunci: Nilai Akhlak, Budaya, Kesehatan, Agama, Silat, Cimande, Konservasi

\begin{abstract}
Pencak silat is part of the Indonesian culture that plays a role in shaping morals towards the environment. This study aims to find the moral values and conservation of the Cimande Pencak silat. The research method used is qualitative method. Collecting data by observation, in-depth interviews, and documentation. Selection of informants with purposive sampling technique. Data analysis with data triangulation approach. The findings show that Cimande Pencak silat has moral values to God, humans, and the environment. If the opponent has lost, they must be respected by not hitting the opponent and insulting the opponent, and not being allowed to step on the opponent. Likewise, with nature, Cimande members are not allowed to throw garbage into the river and treat living creatures like animals properly. Another finding there are several ways to protect Pencak silat from extinction such as releasing literacy to youth about silat, modifying the method, and categorizing silat players from junior and senior as well as promote silat at school. Another finding is that there are health values from the Cimande silat game and contains religious values and there are social values from Cimande Pencak silat activities.
\end{abstract}

Keywords: Morality, Culture, Health, Religion, Silat, Cimande, Conservation

Copyright (c) 2021 Bahagia Bahagia, Rimun Wibowo, Dede Dede, Fitri Amelia, Kartika Amelia, Ilham Nur Hidayat, Mulyana Kosasih

$\triangle$ Corresponding author:

Email : bahagiagia59@yahoo.co.id

DOI : https://doi.org/10.31004/edukatif.v3i4.1077

ISSN 2656-8063 (Media Cetak)

ISSN 2656-8071 (Media Online) 


\section{INTRODUCTION}

Pencak silat is known as a unique Indonesian martial arts cultural heritage that has artistic, knowledge, and learning values. This makes Pencak silat very close to life and the environment where it develops(Wicaksono et al., 2020). Pencak silat is an original martial art from Indonesia, at first, it was created by humans to defend themselves from the threat of wild animals. No one knows when, where, and how the process of developing the sport of Pencak silat first took place, this is because the available information is still very limited. The author describes that: Pencak silat is termed as a term that is debated about its origin, where it comes from, from another place or country which then arrives in Indonesia. However, Pencak silat itself is the result of a combination, not the result of purely autogenic efforts (Manoppo, Mandagi, sungkudon et al., 2021). Martial arts is a sport that requires a high level of concentration in its implementation. Concentration is needed in carrying out attacks such as kicks during matches so that accuracy is maximized (Dewi et al., 2018).

Sukron \& Ricky (2020)said that the factors that influence the change in character are the inculcation of the values of the Pencak silat philosophy, the sincerity and desire of the coaching teacher to improve the quality of training, the control of the coaching teacher towards students, and the desire of students to evaluate themselves. Sin \& Ihsan (2020) said that Pencak silat does not only equip with self-defense skills but on its behalf Pencak silat teaches the perpetrators of the nature of their existence in society and the nature of individuals as creatures created by God Almighty. Through understanding the nature of himself in society and the eyes of his creator, the individual can establish interactions under the provisions that govern them.

Both the provisions in interacting with fellow human beings, as well as interactions with God Almighty. In addition, the opening moves serve as self-defense from enemy attacks, each movement also shows a steady faith in Allah, the suggestion of family harmony, various noble attitudes such as sincerity, devotion to the motherland, self-confidence, optimism, and self-awareness (Ediyono \& Widodo, 2019). Faza \& Ubaidilah (2020) said that this Pencak silat activity contains Islamic educational values, namely the value of faith (I'tiqodiyyah), moral values (khuluqiyyah), and amaliyah values. Based on the concepts and findings above, it shows that silat belongs to the culture of the Indonesian nation which has a function value to shape human morals, both morals to God, humans, and the surrounding environment including nature. It even forms a disciplined, tough, and unyielding character. While silat and nature have a relationship because the game of silat can also be done in the open. Silat means including education, as a human being who wants to gain knowledge than getting knowledge in the open world is a good place. Even the use of the river as a learning resource can be used as a process of training problem-solving skills and can improve the character abilities of students by looking at the state of the surrounding environment that requires handling problems (Anjarwati, 2019).

For that humans must also behave well in the environment. Meanwhile, good behavior towards the environment is strongly influenced by environmental awareness, knowledge, attitudes, and awareness of the environment. Islam regulates human behavior to behave well towards nature (Majeri \& Wibowo, 2018). Allah has reminded us that Allah hates to receive real facts like livestock and plants defective (Qs Al-Baqarah 2:205). Then, people who cultivate seeds or plant to land, the person will receive a reward from God (Ikhtiono et al., 2020). The theory and findings above show that learning by making the outdoors a place of learning that is not bound by space and time has an impact on the ability to receive learning and at the same time not get bored because it is not in the room. Silat games by combining natural nuances during learning or practice will make silat participants love the environment and be physically healthy because they see beautiful nature, rivers, and green areas. At the same time forming good moral behavior towards nature and humans. This research doesn't investigate what the researcher has conducted. The research continues to discover morality value in Pencak silat Cimande including social, nature, and religious morality. The other is to find out about health and social value when the person blends in Pencak Silat Cimande activity. The other is to discover the method or the way to protect Pencak Silat Cimande for circumventing from vanishing. 


\section{METHOD}

This research on morality value and conservation of Pencak Silat Cimande, West Java, uses ethnography with a qualitative approach method. Ethnography is a form of applied and pragmatic ethnography that explores certain social phenomena such as those that occur in everyday life (Bikker et al., 2017). Ethnographic qualitative studies are usually carried out to describe a group's characteristics or society as the subject under investigation (Hanifah, 2016). In this study, it was determined directly the respondents to be used, namely the Pak Dede. Pak Dede is senior of teacher in Pencak Silat Cimande for pergurun Silat Cimande Pajajaran. The respondents are selected because the respondent can reply to all of the questions that the researcher rise. Another reason is Mr. Dede is one person who obtains a high position in the classification of silat ability. Then, the sample enables to gather because the sample understands the content of silat Cimande. There are three methods that the researcher intent to release including in-depth interview, observation, and documentation. In-depth-interview is headed to Mr. Dede to gather numerous information about the objective of major research. Some questions demand to Mr. Dede for replying such as the history of Pencak Silat Cimande like who the first person to create the name of Pencak Silat Cimande and why Pencak Silat is given name as Cimande. Then another question is to investigate the social, environmental value, and religion of Islam in Pencak Silat Cimande.

Social morality includes the behavior in social life and environment morality like how people behave in the environment such as river or water as well as the people ban to throw the sewage to the river. Furthermore, the researcher also asks about the obstacle and the way to embedded Pencak Silat in the young generation were they reluctant to involve in Pencak Silat. Moreover, the researcher also attempts to ask about the method or conservation of Pencak Silat Cimande for avoiding Pencak Silat from extinction. Lastly, the question about the benefit of involving in Pencak Silat for improving human health. Once the data has been gathered from numerous sources, including data from in-depth interviews, observation, and documentation, the overall data is analyzed using a triangulation approach. Sugiyono (2016) states that in qualitative research, data is obtained from various sources. Using various data collection techniques (triangulation), information is carried out continuously until the data is saturated. Meanwhile, triangulation is part of the credibility test. In this, credibility testing is used as a tool to check data from various sources in various ways and at multiple times. Data credibility testing is one of the strengths of qualitative research. This is based on determining whether the findings obtained are accurate from the point of view, participant researchers, or readers (Creswell, 2016). In this research, the mixing of several sources of data such as in-depth-interview, observation, and documentation can mention as valid data.

\section{RESULT AND DISCUSSION}

Pencak silat is Indonesian culture. In Indonesia, Pencak silat has been known for centuries. Martial arts experts and warriors believe that the Malay community created and used this martial art since prehistoric times because at that time humans had to face a harsh and wild nature. This Pencak silat at that time aimed to survive by fighting wild animals. The theories that exist in Pencak silat include having to master breathing, movement, moves, and materials (Mizanudin et al., 2018). Cimande Pencak Silat is located in Tari Kolot, Caringin District, Bogor. Cimande is an acronym for Cai Iman anu Hade. The history of naming this area is related to the river that flows in the area used for ablution by the students in the past. Giving the name became very famous. As for creating Cimande Silat moves based on iktihoroh and istikomah, is this good or not. The Cimande silat stance was created in 1835 by Mbah Khair.

Mbah Khair was one of the first to make Cimande moves. There are 33 moves in Cimande silat. Besides Mbah Khair, there are some students of Mbah Khair namely ayah Ursi and Eyang Ace. Mr. Khair's first student was Eyang Ace. In addition, Mbah Khair's student is H. Abdullah Somad, or Ocot's father. Ayah Ocot grave is in Tari Kolot. The descendants of Ocot's father in Tari Kolot area adhere to the taleq of Cimande. 
Pencak silat Cimande contains moral values. People who learn Pencak silat then their personality is following the taleq of the silat school itself. Each style of Pencak silat has its concept. The main goal is to defeat yourself. Although to beat others is very easy. Cimande silat college has various universities in the province of West Java. There are several silat schools in West Java, starting from Padjajaran Cimande, Padjajaran Nasional, and Pusaka Manggala Cimande. Cimande is a martial arts school but has produced various universities spread across several regions in West Java. There are three sorts of silat in Indonesia, namely the Cimande, Betawi, and Lintau in West Sumatera. In a silat competition, there is a sportsmanship value. For example, in a game using rules. In the past, who was strong then he won. During the match, the legs can be broken and the hands can be broken.

However, at this point, it is no longer allowed to have a match that causes someone pain. The goal is to avoid a commotion from both the coach and the perpetrators of the silat implementer. The value of a punch gets a value of 1 , kicks, both straight kicks, sickles, T, circle get a value of 2 . Drops get a value of 3 . There is another value of 1 plus 2 , a punch is followed by a kick (value $1+2$ ), a punch is accompanied by a fall $(1+3)$ (there is a process like punching then followed by the fall of the opponent). Or 2 plus 3 (kick and he falls) and the value of evasion or a parry, so it's parried first and then punched (1+1). At the time of the match may not make 6 attacks. In ancient times the behavior to fight the opponent could be at will. If someone commits an action more than six times, he will get a warning. In this session, one will not get a deduction. A person can be deducted if during a match he is punched in the head, for this behavior, someone gets a reduction in value even though the person is not hit (deducted 1 point). If someone is punched and the opponent is hit in the face, the value is reduced (the value is reduced by 5). If the punch is straight and the opponent's position is down, it's the fault of the person who punched him. If the opponent is still standing, the person who punched him was the wrong person. The above rules show that there are ethical values. Meanwhile, when playing the Cimande silat, there are moral values based on the Cimande taleq. Taleq Cimande is a code of ethics that must be adhered to and adhered to by Cimande Pencak Silat members as well as possible. Taleq Cimande as a culture has shown the values of life and the meaning of morality which is in harmony with Pancasila.

The contents of Taleq Cimande are Must be obedient to Allah and His Messenger, Do not fight against mothers and fathers and old people, Do not fight against teachers and government, Do not gamble and steal, Do not be arrogant and arrogant, Do not commit adultery, Do not lie and be cunning, Do not get drunk and smoke drugs, Do not be ignorant, persecute fellow creatures of God (should not behave badly to animals and plants), Do not pluck without permission, take without asking, Do not be envious, Do not like not to pay debts. Must be polite, humble, friendly, and mutual respect for fellow human beings, Playing silat is not for valor but to seek the safety of the world and the hereafter. Pencak silat is a native Indonesian culture that has four aspects, namely: mental and spiritual aspects, cultural arts aspects, martial arts aspects, and sports aspects (Kholis, 2016). The religious values contained in Cimande Pencak Silat are interrelated because the content in Cimande taleq itself is related to what Allah SWT has ordered regarding moral values. It is the first in taleq Cimande which it has strong linkage to human must subdue to Allah. The purpose of human creation is only to worship Allah the Creator. Worship is meant here very broad meaning, which includes in all human actions, not limited to mahdhah worship only. Therefore, God made man as His vicegerent on earth, so that humans regulate or manage this earth according to the potential that exists in each of them because Allah does not will ask for accountability beyond the capabilities that have been given to humans (Muhammad, 2017). According to Pak Dede, the application of taleq Cimande in the field is that the members of Pencak silat do not immediately start Pencak silat activities, let alone accepting new members, it is necessary to first know what their intentions are for knowledge.

Then, every time you start an exercise activity, praying to God, namely Allah, is the first activity you do before moving on to the next step. Allah is not forgotten when starting the Pencak silat activity. Another morality value is nature morality. The content of Taleq Cimande has a strong connection to adjust the 
behavior to live harmony with around nature environment. One Taleq Pencak Silat Cimande has a connection to nature is not ignorant, persecute fellow creatures of God. In this taleq have connected to human must respect to nature. Sir Dede reported when the interview is held, he said that humans may not devastate nature such as animals and plants. Even humans are prohibited to utilize the river as a place to throw the garbage. Mr. Dede also said that when the member of Pencak silat Cimande begins the training, they have to take a bath in the river and do ablutions (wudhu). It shows that members of Pencak silat are close to nature like water. In addition, Pencak Silat activity like training is better releasing in nature such as in rice paddy field and near river. Meaning that the person who involves in Pencak Silat Cimande must avoid the devastating of nature. This finding shows that Taleq Cimande teaches the member of Pencak Silat doesn't ravage the environment. From an Islamic perspective, a person must protect nature from damaged.

In the Qur'an, Allah says: And when it is said to them, Do not cause mischief on the earth." They replied, "Indeed, we are the ones who make repairs (Al-Baqarah: 11). The prohibition on destroying and preserving the environment has been explained in the hadith, the prohibition against destroying trees has been carried out since the time of Prophet Ibrahim until the time of the Prophet Muhammad. From Jabir r.a, the Messenger of Allah said "That Prophet Ibrahim has forbidden the land of Mecca and I forbid the land of Medina including two rocky valleys. No, the tree may be cut down and the animals may not be hunted (HR Imam Muslim). The discovering is boosted that humans are part of the universe (kosmos) that has been created by Allah SWT and as His servants. Humans are given the power by God to utilize, cultivate, and maintain the potential of the universe that $\mathrm{He}$ has created (khalifatullah). With nature, humans also process and obtain knowledge from God. Therefore, discussing the relationship between humans, nature, and Allah SWT as the creator cannot be separated (Samidi, 2016). Even humans and their natural surroundings are a means to increase knowledge, gratitude, and get closer to God (Alim, 2020).

The Cimande elders made Pencak silat to perfect morals, not for valor but to seek the safety of the world and the hereafter. In the past, the young man liked to play cockfighting. With the Cimande Pencak silat, young people no longer join these activities. This is following the hadith of the prophet and the teachings of Islam. Another value is taleq Cimande lead to build social morality in social life like a person must be wellbehaved to their parent as other content of taleq Cimande. Muslims who have good morals for sure will respect and be filial to their parents. Therefore all forms of behavior of a child who declares himself Muslim should realize these two sources in everyday life, both in the community and school environment. Even more specialized in the environment family. Because in the family environment both parents have to take care of and look after their children (Sari et al., 2020). A child has various obligations to their parents ranks second after Allah SWT, and is forbidden to disobey parents (Nufus et al., 2018). The other refers to the relationship of parents and children in the world in the form of rights and obligations. Children's rights to education, income, and inheritance. As for the rights of parents to get good treatment, affection, and prayer from their children. In addition, this research also shows that in the afterlife, the relationship between children and parents can be established if based on faith and diversity (Kharomen, 2019). Silat Cimande by Mbah Khair was made to improve morals. In the past, youths liked to spar with cocks. The presence of playing silat can reduce these problems. If you have made 6 attacks, someone has lost the match, that is, you can't tread. If ridiculed, it is a serious offense. Second, if the opponent has lost, the opponent cannot be attacked again. For example, if the opponent has lost while the loser was still kicked and beaten, it is a serious violation.

When it is still being resisted, it can cause conflicts that come from the audience. This method is a way to respect the opponent. In the view of Islam, the behavior applied in taleq Cimande and behavior during martial arts shows that Cimande Pencak silat upholds moral values in Islam. Then, the social value of Pencak silat includes us studying not only for morals but also for social values. For example, when a fighter member is sick, we can visit that person. Another example is when at the time of the match, there is a noisy college so we can solve the problem together. So it looks like a brotherhood between each other. Meanwhile, to preserve 
Pencak silat in Indonesia, the younger generation today must be literate about silat. Do not let them prefer martial arts from outside Indonesia such as karate and kung fu. Efforts are to carry out activities such as matches or events so that generations are interested in participating in self-defense. Moreover, seeing Pencak silat with good martial arts. Seeing this event causes the younger generation to be interested even though the event is not that big. The second effort is that members must come from schools. Third, holding Pencak silat training. So the coach is not arbitrary, a silat coach must be able to manage and choose which targets. This effort is part of preserving the culture of Pencak silat. We must also be aware that Pencak silat has reached the international level. Last year, Indonesia had won against various countries. Even though we've lost before. The countries that won in Pencak silat were Malaysia and the Netherlands.

This fact proves that this silat game is already known in the world and they are learning. For example, teachers from Cimande are offered to teach in various countries such as America, Netherlands, and England. Financially, when teaching silat in the world, the economy will get a bigger economy compared to training in Indonesia. This is the reason why Pencak silat is very developed in the world. For example, being a coach for 1 year can buy a car even though the main goal is to preserve the nation's culture. When you practice silat abroad, you can get the economic value of up to hundreds of millions of rupiah. For this reason, several things need to be done to motivate the younger generation, such as modifying methods. If you follow the ancient method then it may not develop. For this reason, the method must adapt to the current era so that the current generation will follow suit. In ancient times, the practice did not use props. Currently, he uses props such as a rectangular kickbox and hand box. One of these goals is to avoid feeling bored with the old method but still maintain the value of Pencak silat. Do not use a new method that is not following the values in Pencak silat.

Besides that, we are given an understanding that playing Pencak silat can have economic value so that it is useful for life. Then, use the curriculum. Then there is the belt level when you are in the desert. Although previously there were no levels of this belt. This classification is what appeals to the younger generation. There are several levels of belts including green, blue, brown, black belts. With the belt level, there is an ego to maintain to continue to rise. It's different from the practice of buhun-buhun so watching even though it should be like that but to make the younger generation interested. There are juniors and seniors. Then, playing silat Cimande provides health value. Treatment of fractures, drinking Cimande oil. If the wound uses Cimande oil, the wound can heal. When you want to be strong, you have to use Cimande oil so it will be resilient when playing silat. To consume Cimande oil must have reached 20 years because of the nature of Cimande oil to ward off disease. If the child is under the age of 20 , it is not permissible to drink it, but it can be smeared with the oil. If we exercise a lot it will increase immunity. The more often a person exercises, the more disease he avoids Before training, there is a warm-up so that is included in health. When you do exercise, you will sweat. When sweat comes out during silat practice, the body's toxins will come out through sweat.

Similarly, the role of silat is developing in addition to protecting oneself to become one of the means in efforts to maintain health through the field of a sport so that physical and spiritual balance is one way in increasing community productivity (Mardotillah \& Zein, 2017). Cimande silat has various characters, namely movements that are different from other types of silat in Indonesia, such as in West Sumatra. Then what distinguishes the Cimande silat the most is the dry bones. The shin is famous for the Pencak drum. Second, Pencak silat can treat broken bones. If you go to any country, it is famous for the treatment of fractures, so it is famous for fractures. So if in Cimande you learn silat, there is also treatment for broken bones. There are even other colleges to study in when it comes to fractures. There are no other colleges yet, when Cimande College meets with other universities when there is an event, the other colleges usually ask to be sorted. In addition, hand strength. Cimande people than just block it by hand. Not all colleges develop fracture methods. Cimande Pencak silat also contains religious values ranging from humans created only to worship God. The oath of the desert includes piety to God Almighty. To support silat activities, there are religious activities carried out including the birthday of the prophet Muhammad SAW. 
2328 Social, Nature, Religion Morality and Protecting of Pencak Silat Cimande - Bahagia Bahagia, Rimun Wibowo, Dede Dede, Fitri Amelia, Kartika Amelia, Ilham Nur Hidayat, Mulyana Kosasih

DOI: https://doi.org/10.31004/edukatif.v3i4.1077

\section{CONCLUSION}

There is a connection between religion and Pencak Silat Cimande such as before beginning the training, the member of Pencak Silat must take a bath and then taking ablution. Even the member never forget praying before starting the training. Nature and social morality are implemented in Pencak Silat Cimande. Each person of member ban to ravage nature like throwing garbage to the river as well as they must applicate good behavior to the creature life like animals. It is supported that training better release in rice paddy fields, rivers, and the nature area. Socially, If the opponent has been subdued, they must be respected and not combating the opponent. The frenemy also is not humiliated and not being allowed to step on the opponent. Another finding is that the Cimande Pencak silat must be preserved so that it can continue to be sustainable for today's young generation through literacy to youth about silat, modifying the silat method so that it is following current conditions, and the existence of categorization of the silat players starting from junior and senior as well as literate about silat in school. Silat also has health values because every person who embroiling in Pencak silat can perspire and abolish the poison content in the body through sweating.

\section{REFERENCES}

Alim, A. S. (2020). Hakikat Manusia, Alam Semesta, dan Masyarakat dalam Konteks Pendidikan Islam. Jurnal Penelitian Keislaman, 15(2), 144-160. https://doi.org/10.20414/jpk.v15i2.1760

Anjarwati, S. (2019). Pemanfaatan Alam Terbuka Sebagai Sumber Belajar Biologi. Bioedukasi (Jurnal Pendidikan Biologi), 10(1), 55. https://doi.org/10.24127/bioedukasi.v10i1.2009

Bikker, A. P., Atherton, H., Brant, H., Porqueddu, T., Campbell, J. L., Gibson, A., McKinstry, B., Salisbury, C., \& Ziebland, S. (2017). Conducting a team-based multi-sited focused ethnography in primary care. BMC Medical Research Methodology, 17(1), 1-9. https://doi.org/10.1186/s12874-017-0422-5

Creswell, J.W. (2016). Educational Research: Planning, counducting, and evaluating quantitative and qualitative research. Upper Saddle River. NJ: Merrill.

Dewi, A., Setiawan, D., \& Yuliandi, R. (2018). Pengaruh Meditasi Dalam Meningkatkan Akurasi Tendangan Pada Atlet Pencak Silat Di Organisasi Psht Kabupaten Banyuwangi. Jurnal Kejaora (Kesehatan Jasmani Dan Olahraga), 3(1), 154-161. https://doi.org/10.36526/kejaora.v3i1.203

Ediyono, S., \& Widodo, S. T. (2019). Memahami Makna Seni dalam Pencak Silat. Panggung, 29(3). https://doi.org/10.26742/panggung.v29i3.1014

Faza, S., \& Ubaidilah, S. (2020). Urgensi Nilai-Nilai Pendidikan Islam dalam Kegiatan Pencak Silat Gasmi di Pondok Pesantren Al-Mahrusiyah Lirboyo Kediri. Jurnal Intelektual: Jurnal Pendidikan Dan Studi Keislaman, 10(1), 1-10. https://doi.org/10.33367/ji.v10i1.1037

Hanifah, N. (2016). Teori Penerjemahan Sebagai Dasar Pembelajaran Penerjemahan: Studi Kualitatif Etnografi Ninip Hanifah Translation Theory As The Foundation Of Translation Learning: A Qualitative-Ethnographic Study. Cakrawala Pendidikan, XXXV(2), 254-263.

Ikhtiono, G., Bahagia, B., Wibowo, R., \& Mangunjaya, F. M. (2020). Land Conservation and Pest Management of Agriculture Perspective Islamic Religion. SALAM: Jurnal Sosial Dan Budaya Syar-I, 7(11), 977-992. https://doi.org/10.15408/sjsbs.v7i11.17776

Kharomen, A. I. (2019). Kedudukan Anak dan Relasinya dengan Orang Tua Perspektif Al-Qur'an. Andragogi: Jurnal Diklat Teknis Pendidikan Dan Keagamaan, 7(2), 198-214. https://doi.org/10.36052/andragogi.v7i2.88

Kholis, M. N. (2016). Program Studi Pendidikan Jasmani Kesehatan Dan Rekreasi Universitas Nusantara PGRI Kediri 1. Jurnal Sportif, 2(2), 76-84.

Majeri, F., \& Wibowo, R. (2018). Attitude , Knowledge , Awareness Environment Based on Islamic View Toward Behavior For Protecting. Spatial : Wahana Komunikasi Dan Informasi Geografi|19, 20(2), 19- 
2329 Social, Nature, Religion Morality and Protecting of Pencak Silat Cimande - Bahagia Bahagia, Rimun Wibowo, Dede Dede, Fitri Amelia, Kartika Amelia, Ilham Nur Hidayat, Mulyana Kosasih

DOI: https://doi.org/10.31004/edukatif.v3i4.1077

28.

Mardotillah, M., \& Zein, D. M. (2017). Silat: Identitas Budaya, Pendidikan, Seni Bela Diri, Pemeliharaan Kesehatan. Jurnal Antropologi: Isu-Isu Sosial Budaya, 18(2), 121. https://doi.org/10.25077/jantro.v18i2.62

Mizanudin, M., Sugiyanto, A., \& Saryanto. (2018). Pencak Silat Sebagai Hasil Budaya Indonesia. Prosiding SENASBASA, 264-270. http://researchreport.umm.ac.id/index.php/SENASBASA\%0A(Seminar

Muhammad, M. T. (2017). Kualitas Manusia Dalam Pandangan Al-Qurâ $€^{\mathrm{TM}}$ an. Jurnal Ilmiah Al-Mu'ashirah, 13(1), 1. https://doi.org/10.22373/jim.v13i1.2348

Nufus, F. P., Agustina, S. M., Lutfiah, V. L., \& Yulianti, W. (2018). Konsep Pendidikan Birrul Walidain Dalam Qs. Luqman (31): 14 Dan Qs. Al - Isra (17) : 23-24. Jurnal Ilmiah Didaktika, 18(1), 16. https://doi.org/10.22373/jid.v18i1.3082

Samidi, S. (2016). Tuhan, Manusia, dan Alam: Analisis Kitab Primbon Atassadhur Adammakna. SHAHIH: Journal of Islamicate Multidisciplinary, 1(1), 13. https://doi.org/10.22515/shahih.v1i1.47

Sari, L. E., Rahman, A., \& Baryanto, B. (2020). Adab kepada Guru dan Orang Tua: Studi Pemahaman Siswa pada Materi Akhlak. Edugama: Jurnal Kependidikan Dan Sosial Keagamaan, 6(1), 75-92. https://doi.org/10.32923/edugama.v6i1.1251

Sin, T. H., \& Ihsan, N. (2020). The effectiveness of Pencak Silat to change teenage personalities. Jurnal Konseling Dan Pendidikan, 8(1), 1. https://doi.org/10.29210/139800

Sugiyono. (2016). Metodologi Penelitian Kuantitatif, Kualitatif, dan R\&D. Bandung: CV Alfabeta.

Sukron, M., \& Ricky, Z. (2020). Peningkatan Karakter Peserta Didik (Religius, Jujur, Dan (Disiplin) Melalui Pencak Silat. De_Journal, 1(1), 1-9. https://ejournal.undhari.ac.id/index.php/de_journal/article/view/31

Tendangan, T., Pencak, D., Manoppo, B. E., Mandagi, H. S., \& Sunkudon, D. (2021). Jurnal Ilmu Kesehatan Olahraga. 2(1), 9-13.

Wicaksono, R. W., Nur Izzati, \& Tambunan, L. R. (2020). Eksplorasi Etnomatematika pada Gerakan Pukulan Seni Pencak Silat Kepulauan Riau. Jurnal Kiprah, 8(1), 1-11. https://doi.org/10.31629/kiprah.v8i1.1596 